\title{
Comunicação política e diplomática no reinado de D. João III : redes de informação e estratégias de manutenção de segredos ${ }^{\mathrm{I}}$
}

\author{
Raphael Henrique Dias Barroso
}

Mestrando do Programa de Pós-Graduação em História Social da Universidade de São

Paulo (USP)

\section{Resumo}

Neste trabalho, analisaremos as diferentes práticas de transmissão de informações entre a Coroa portuguesa e os embaixadores na Europa, durante o reinado de D. João III (I52I-I557). Em primeiro momento, buscaremos investigar as instruções para o envio da correspondência, as informações que circulavam e as rotas de transporte. Em seguida, a fim de compreender as estratégias de manutenção de segredos, apontaremos o uso de variadas práticas de escrita, silêncio, ocultamento de informações e criptografia das mensagens. Por fim, sem a pretensão de esgotar o tema, concluímos que a expansão do quadro de diplomatas esteve ligada à modernização dos transportes, ao aprofundamento das conexões entre as cortes e à alta demanda de informações.

Palavras-chave Diplomacia - D. João III - Comunicação - Práticas de escrita.

\section{Abstract}

This work discuss the ways the Portuguese Court and its ambassadors in Europe shared information during the reign of D. João III (I52I-I557). First, we investigate the instructions on sending letters, the flow of information and its transportation routes. Next, we look at cases of writing, silences, the hidden and the cyphers, to understand the different strategies of concealment. Lastly, without exhausting the topic, we conclude showing that diplomacy in this period is connected with the modernization of transports, the deepening of connections between the Courts of Europe and the high increase in the demand for information.

Keywords Diplomacy - D. João III - Communication - Writing Pratices.

\section{Submissão}

27/07/2020 Aprovação

IO/IO/2020 Publicação

$30 / 12 / 2020$

Parte desse trabalho está sendo publicado no livro digital do I Seminário Dinâmicas Imperiais, Circulação e Trajetórias no mundo ibero-americano organizado pela Universidade Federal de São Paulo (UNIFESP). Agradeço à CAPES pelo financiamento da pesquisa de mestrado. 
$\mathrm{N}$ o dia 24 de dezembro de 1527, o embaixador português João da Silveira, escrevia de Paris, na França, ao rei D. João III com grande urgência. Era a segunda vez que copiava a mesma informação, mas temendo que sua carta não chegasse, não tomou tempo em escrever novamente: "Porque podera ser que as cartas que envio a Vossa Alteza por este portador não passarão leva esta em mais segredo". ${ }^{2}$ João da Silveira informava que havia chegado navios franceses nos portos de Ruan, com inúmera quantidade de pau-brasil. Eram corsários autorizados pelo rei Francisco I a comercializarem o produto ao sul do Atlântico e o embaixador persuadia o rei a tomar uma atitude rápida, pois: "Doutra maneira tudo se perderaa". ${ }^{3} \mathrm{O}$ problema com os corsários franceses foi um dos principais motivos que levaram a Coroa lusitana a ocupar as terras recém adquiridas pelo Tratado de Tordesilhas. ${ }^{4}$ Entretanto, voltandonos à escrita da carta do embaixador, a preocupação, após ter finalizado a missiva, era que a informação fosse por uma rota diferente da primeira carta enviada, a fim de garantir a chegada de ao menos uma das cartas a Portugal, o mais ligeiramente possível: "por mayor presteza mandey despachar este por maar, por honde pareceo que com mais brevidade podia passar".

A comunicação do rei com seus mais distantes servidores, dos embaixadores na Europa aos vedores na Índia, é parte do objeto que discutimos neste artigo. Durante o reinado de D. João III (I52I-I557), as informações corriam com acentuada velocidade dado ao desenvolvimento do sistema de transportes marítimos, mas também por uma transposição crescente de documentos manuscritos e impressos, tanto pela acessibilidade do papel, quanto pelo aumento dos escrevedores de cartas nas praças públicas do reino. ${ }^{6}$ Para suprir a demanda crescente de informações, a partir do reinado

2 JOÃO DA SILVEIRA. “Carta a D. João III de 24 dez. I527”. In: VENTURA, Margarida Garcez. João da Silveira: diplomata português do século XVI. Lisboa: Gabinete Português de Estudos Humanísticos, 1983, p. 168.

3 Ibidem, p. 169.

4 Outra foi a intensa rivalidade com os castelhanos e aragoneses, súditos do imperador Carlos V, pela posse das ilhas Molucas e pela navegação do rio da Prata, principalmente, pela divergência quanto a demarcação das regiôes, dada a cobiça com a descoberta das minas de prata e pelo comércio das especiarias. RICUPERO, Rodrigo. A Formação da Elite Colonial no Brasil: (de I530 a 1630). 2르 ed. São Paulo: Almedina, 2020, pp. IO4-IO5.

5 JOÃO DA SILVEIRA. “Carta a D. João III de 3r mai. Is28”. In: VENTURA, Margarida Garcez. Op. Cit., p. 175.

6 Sobre o tema ver em: MIRANDA, Tiago Costa Pinto dos Reis; LISBOA, João Luís. "A cultura escrita nos espaços privados". In: MONTEIRO, Nuno Gonçalo (org.). História da Vida Privada

I58 • ano XI, n. 16, 2020 • ISSN 2179-5487 
de D. Manuel (I495-I52I), institui-se em Roma, a embaixada permanente, afim de garantir a frequência e segurança dos correios. Como assinala Pedro Cardim: "Até o reinado de $\mathrm{D}$. Manuel I as poucas iniciativas diplomáticas que tiveram lugar visaram sobretudo sanar conflitos com os demais príncipes, ou então negociar casamentos régios".7 Porém, foi no reinado de D. João III que os embaixadores permanentes ou residentes, expandiram-se pelas cortes da Europa, como a França, Inglaterra e o Sacro Império Romano Germânico. Esses tinham duas funções mais comuns: ou "residir", serem os informantes de todas as notícias requisitadas pela Coroa, ou "visitar", embaixadores enviados de forma extraordinária para negociar tratados, casamentos, ou participar de festividades da corte. ${ }^{8}$

Nesse período, a ampliação do quadro de diplomatas veio em um momento de extrema necessidade da Coroa portuguesa para a defesa das conquistas ultramarinas. ${ }^{9}$ Nos primeiros meses do reinado de D. João III, surgiu um problema até então inexistente nos reinados anteriores: a quebra do domínio português na navegação e comércio nas terras de além-mar. Os reinos vizinhos da Península Ibérica, que tinham sido herdados por Carlos I da Espanha (eleito como imperador Carlos V em I519), formavam um grande império em vários continentes, ameaçando os domínios portugueses, com a chegada de Fernando de Magalhães às ilhas Molucas. ${ }^{10}$ Além do mais, corsários franceses constantemente atacavam as naus no oceano Atlântico, causando grandes prejuízos nas fazendas do reino. Consequentemente, foi preciso uma intensa atividade diplomática, especialmente com a Cúria romana, a fim de obter bulas e tratados que legitimavam a posse das novas conquistas. Assim, era de extrema importância a manutenção de um sistema de comunicação com os embaixadores.

Contudo, vale destacar que mesmo as cartas dos embaixadores endereçassem ao rei, esse não era o único a ter acesso as missivas. Os conselheiros e os mais próximos fidalgos do monarca tinham acesso irrestrito, tanto ao despacho, quanto no

em Portugal. A Idade Moderna. Lisboa: Círculo de Leitores, 20II, p. 335; BUESCU, Ana Isabel. "Cultura manuscrita e impressa em Portugal na Época Moderna”. Penélope. № 2I, 1999, pp. II-32.

7 CARDIM, Pedro. "A diplomacia portuguesa no tempo de D. João III. Entre o Império e a Reputação". In: CARNEIRO, Roberto; MATOS, Arthur Teodoro de. D. João III e o Império. Actas do Congresso Internacional comemorativo do seu nascimento. Lisboa: Centro de Estudos dos Povos e Centro de História e Além-Mar, 2004, p. 629.

8 MATTINGLY, Garrett. Renaissance Diplomacy. Boston: The Riverside Press/Cambridge, 1955, pp. 240-254. Ver também em: BÉLY, Lucien. L'art de la paix en Europe. Naiscance de la diplomatie moderne. XVIe-XVIIIe siècle. Paris, PUF, 2007.

9 MARCOCCI, Giuseppe. A Consciência de um Império. Portugal e o seu mundo (sécs. XV-XVI). Coimbra/PT: Imprensa da Universidade de Coimbra, 2012, p. 24.

Io Sobre as controvérsias da viagem de Fernando de Magalhães: SOLER, Isabel. "Magallanes y el dibujo del mundo". Anais de História de Além-Mar, № 20, 2019, pp. 17-60. 


\section{REVISTA ANGELUS NOVUS}

recebimento das informações. Foi por essa razão que João da Silveira, antes de pedir auxílio ao tesouro da Coroa, devido aos custosos gastos na corte francesa, preferiu omitir alguns valores: "E não diguo ysto porque crea ter imyguos no Conselho de Vossa Alteza, ante cuydo que todos me querem bem e a todos o quero". "Quando as informaçôes chegavam, as primeiras medidas eram garantir o sigilo, apartar os "indesejados" e impedir que as informações circulassem. "No he podido saber lo que el mensajero del Rey traxo de Francia” - dizia impacientemente o embaixador castelhano Lope Hurtado de Mendonça. ${ }^{12}$ Outros, como os núncios em Portugal, também eram constantemente impedidos de terem acesso. Marco Vigério della Rovere, por exemplo, escrevendo para Jacopo Salviati, secretário do papa Clemente VII, informava que quatro importantes figuras da corte tinham presença constante no círculo mais íntimo do monarca. Em primeiro lugar, vinha o conde de Castanheira e vedor da fazenda, Antônio de Ataíde: "di piú favore et autoritá appresso il re di alcun altro" ${ }^{13}$ Em seguida, o infante D. Luís, duque de Beja e condestável do reino: "molta gentil persona"; ${ }^{14} \mathrm{D}$. Miguel da Silva, bispo de Viseu e escrivão da puridade: "di molto buon credito et fa molte facende". ${ }^{\text {s }}$ Por fim, o conde de Vimioso, Francisco de Portugal: "fratello del signor Don Martino [D. Martinho de Portugal, embaixador em Roma], è ancor lui molto innanzi et di grande autorità". ${ }^{16}$

II JOÃO DA SILVEIRA. “Carta a D. João III de 29 fev. 1528”. In: VENTURA, Margarida Garcez. Op. Cit., p. I7o.

I2 LOPE HURTADO DE MENDONZA. "Carta a Carlos V de 5 dez. I528”. In: VIAUDE, Aude. Correspondance d'um ambassadeur castillan au Portugal dans les ánnees 1530. Paris: Centre Culturel Calouste Gulbenkian, 200I, p. 307.

13 "de maior favor e autoridade próxima ao rei que qualquer outro". (Tradução Nossa). MARCO VIGERIO DELLA ROVERE. "Carta a Jacolpo Salviati de is out. I532". In: WITTE, CharlesMartial de. La Correpondance des Premiers Nonces Permanents au Portugal I532-I553. Vol. 2. Lisboa: Academia Portuguesa da História, 1980, p. 18.

I4 “pessoa muito gentil”. (Tradução Nossa). Ibidem, p. I8.

Is "de muito bom prestígio e que cumpre muitas tarefas". (Tradução Nossa). Ibidem, p. I9.

16 "irmão do senhor D. Martinho, está mais a frente que ele e é grande autoridade". (Tradução Nossa). Ibidem, p. 19. Nem sempre os membros do Conselho de D. João III foram os mesmos, pois, ora faleceram, como o marques de Vila Real de Portimão, D. Martinho de Castelo Branco e Francisco de Portugal, ora se afastaram e foram novamente reintegrados, como Antônio de Ataíde, ora foram expulsos e perseguidos como D. Miguel da Silva, ou se incorporaram novos, como a Catarina da Austria, mulher de D. João III, Fernão de Álvares de Andrada, tesoureiro da Coroa e o cardeal D. Henrique, inquisidor-mor de Portugal. Mas assim como os conselheiros, os membros da Mesa de Consciência, criada em I532, também eram centrais nos despachos régios, principalmente, quando se tratava de responder aos breves e bulas enviados pelo papa. Entre eles, D. Fernando de Vasconcelos, bispo de Lamego, Afonso do Prado, lente de Teologia da Universidade de Coimbra; João Monteiro, desembargador do Paço, Rodrigo Gomes Pinheiro, bispo de Angra, Antônio Rodrigues, prior de Monsanto e juiz geral da Ordem de Cristo e Frei Gaspar do Casal, bispo de Funchal. Sobre os "protagonistas" do governo, ver em: BUESCU, Ana Isabel. Dom João III (I5o21557). Coletânea Reis de Portugal. Rio de Mouro/PT: Temas e Debates, 2008, pp. 239-263.

I6o $\bullet$ ano XI, n. I6, 2020 • ISSN 2I79-5487 
Assim, compreendemos a comunicação política, como as formas de transmissão de informações entre os principais representantes do governo, a partir da troca de cartas e documentos escritos, o objetivo desse artigo é investigar aspectos da comunicação da Coroa portuguesa no reinado de D. João III. ${ }^{17}$ Em outras palavras, importa-nos as formas de coleta e transmissão de informações, a partir da correspondência do monarca com seus embaixadores, tais como: o despacho e o envio dos correios, os caminhos que eram tomados, as instruções do rei, as diferentes práticas de escrita, além da manutenção do segredo e do uso de uma linguagem criptografada para assegurar o envio das informações. Dessa forma, pretendemos argumentar que a prática da diplomacia permanente serviu como um importante instrumento de coleta e transmissão de informações à defesa das conquistas e da soberania do reino. Assim como demonstrar que a procura pela abertura de canais de comunicação com as embaixadas permitiu o desenvolvimento de estratégias de manutenção de segredos e diferentes práticas de escrita, semelhantemente ao que as Coroas europeias também praticavam. ${ }^{\mathrm{I}}$

\section{As redes de informação e o "correio volante"}

Ao instituir a embaixada permanente em Roma, D. Manuel também concedia ao papado o estabelecimento da nunciatura portuguesa, em I5I3, isto é, o papa e o rei tinham informantes e vias de comunicação permanentes em ambos os territórios e os soberanos concordavam em proteger e garantir que as informações chegassem a cada um. Embaixadores e núncios eram autorizados a enviarem informações sempre que possível, o que indicava que os soberanos garantiam que os embaixadores mantivessem contato mesmo que remoto, sem extraviar as mensagens ou interferir nas comunicações. Foi o que, por exemplo, assinalou o papa Leão X, ao enviar de presente ao rei D. Manuel, a espada e o chapéu consagrados em dezembro de I5I4, por via do embaixador João de Faria:

Quod ut tibi gratius esset, mittimus illud per dilectum fillium Joannem de faria militem militae Jesu Christi, apud nos et sedem cum prudentia et dexteritate perfunctum, qui egregiam voluntatem et paternam benivolentiam erga te mostram longe plenius presens Tibi communicabit. ${ }^{19}$

I7 Para o conceito de comunicação política: DE VIVO, Filippo. Information and Communication in Venice. Rethinking Early Modern Politics. Oxford/UK: Oxford University Press, 2007, pp. 2-3.

I8 TALLON, Alain. L'Europe au XVIe siècle. États et relations internationales. Paris: PUF, 2oIo, pp. 129-165. 


\section{REVISTA ANGELUS NOVUS}

Veio conjuntamente ao estabelecimento das embaixadas, a criação de sistemas postais régios na Península Ibérica, como o Correio Mayor de Castela em I505, criado por Felipe de Gante, pai do imperador Carlos V, que promoveu a ampliação das vias de comunicação entre os reinos ibéricos com os domínios Habsburgo (como os Países Baixos e os principados alemães). ${ }^{20}$ Além do Correio-mor em Portugal, criado em seis de novembro de I520 por D. Manuel, que concedia ao capelão Luís Homem o ofício e o monopólio das postagens num raio de cinco léguas em torno de Lisboa. ${ }^{21}$ D. João III, quando assumiu o trono, ampliou os limites para o Correio-mor, concedendo aos descendentes de Luís Homem, animais e objetos de segurança pessoal, como espadas e punhais, além de permitir que atravessassem as fronteiras do reino, chegando até mesmo à cidade de Roma.22

Todavia, antes mesmo da instituição do correio régio em Portugal, D. Manuel já dava indícios que a comunicação com a embaixada romana era uma prática constante à Coroa. Em julho de 1517, o embaixador D. Miguel da Silva indicava o curto prazo para a chegada do seu maço de cartas, avisando que a troco de cem ducados, a "posta", o envio do correio de Roma a Portugal, levaria suas mensagens em quinze dias ou menos. ${ }^{23} \mathrm{Em}$

I9 "O qual presente [espada e chapéu], para que seja ainda mais agradável para ti, mandamo-lo pelo amado filho João de Faria, soldado da ordem de Jesus Cristo, tendo cumprido seu longevo cargo com extrema prudência e habilidade como embaixador de Sua Majestade junto de nós e da Sede Apostólica, que presente comunicará a ti, a muito mais completamente a nossa distinta vontade e paterna benevolência para contigo". (Tradução nossa). LEÃO X. "Breve Imitati vetus de 30 jan. de I5I5”. In: SILVA, Luís Augusto Rebello da; LEAL, José da Silva Mendes (orgs.). Corpo Diplomático Português, contendo os actos $e$ as relações politicas e diplomáticas de Portugal com as diversas potências do mundo desde o século XVI até os nossos dias. Vol. I. Lisboa: Academia das Ciências de Lisboa, I862, p. 310. (Adiante abreviatura CDP).

20 GÓMEZ, Antonio Castillo. "Me alegraré que al recibo de ésta'. Cuatrocientos años de prácticas epistolares (siglos XVI a XIX)”. Manuscrits. № 29, 20II, p. 28.

2I Arquivo Nacional da Torre do Tombo, Chancelaria de D. Manuel. Livro 37, folhas 98 e 98v. (Adiante abreviatura $A N T T$ ). Sobre o ofício do Correio-mor ver em: NETO, Margarida Sobral (org.). As Comunicações na Idade Moderna. Lisboa: Fundação Portuguesa das Comunicações, 2005 , p. 16.

22 ANTT, Chancelaria de D. João III. Doações. Livro 6o, folha 89. A pena por portar espadas, punhais ou adagas sem a permissão da Coroa era de quatro mil reais, mais dois anos de prisão e açoite em praça pública, excetuando "pessoas de qualidade que nom caiba açoute, alem das sobreditas penas”. ORDENAÇÕES DO SENHOR DOM MANUEL I. Livro I. Título LVII: Das armas que sam defesas, e quando se deuem perder assi de dia como de noute. E dos que sam achados despois do sino de correr. Lisboa: Real Imprensa da Universidade de Coimbra, I786, p. 394.

23 D. MIGUEL DA SILVA. “Carta a D. Manuel de i jul. I5I7”. In: CDP. Vol. I, p. 474. A “posta” que deriva dos cavalos de corrida que levavam os “correios” (aqueles que guiavam os cavalos), indicava também um acordo particular feito por dois soberanos que só seria feito através de carreiras de cartas entre as cortes. Ver verbetes em: COVARRUBIAS OROZCO, Sebástian de. Tesoro de la lengua castellana, o española. Madrid: Impresso por Luís Sanchez, I6II, s. v. "Postas", folha 593 verso; BLUTEAU, Raphael. Vocabulario portuguez ES latino: aúlico, anatomico, architectonico. Vol. 6. Coimbra/PT: Colégio das Artes da Companhia de Jesus, I7I2-1728, s. v. "Posta”, p. 645.

I62 • ano XI, n. I6, $2020 \cdot \mathrm{ISSN} 2 \mathrm{I} 79-5487$ 
30 de dezembro de I526, D. Martinho de Portugal anunciava um pouco mais: "Ha de ir em XVII dias”. ${ }^{24}$ Essa rápida circulação fez D. Manuel, em maio de I5I8, nomear a correspondência com seus embaixadores de "correio volante", uma vez que ele e seus embaixadores dispunham de diversas vias possíveis para que as notícias circulassem entre o reino e o papado. No pedido de dispensa para o casamento com Leonor de Áustria, o rei deixava claro essa circularidade dos correios: "E como for avida e espedida a bulla a despachay e enviay por coreo volante, pera logo per vertude da dita dispensação, e pello poder nosso que pera yso tem, sermos Recebido por pallauras de presente com a dita Ifante". ${ }^{25}$

D. João III seguiu a política do pai e fez largo uso do correio volante. Nas instruções aos embaixadores residentes, bem como nas cartas de crença, a função de informar ao soberano era a característica primordial dos enviados no solo europeu. Para cumprirem essa função, era necessário que o embaixador estivesse sempre próximo ao monarca para qual fosse enviado, de forma a estar sempre atento a tudo que ocorresse com ele e no seu entorno. Tal qual João da Silveira, enviado a corte francesa em cinco de fevereiro de 1522, que deveria ir ao encontro do rei Francisco I não importasse em que lugar seria: "E se tu em Paris o nom achares, seguires a si por postas atee onde ele estever". ${ }^{26}$ Aos embaixadores que eram enviados para residir na corte do Sacro Império, D. João III também ordenava que lhe fosse enviado cartas sobre todas as notícias que tivessem e que seriam importantes para a sua governação. Ademais, o rei informava que trataria de responder o mais brevemente possível, assim que a necessidade pedisse. Foi o caso de D. Francisco Lobo, que esteve na corte do imperador Carlos V entre I539 e I542 (momento de sérios conflitos com os otomanos após a derrota cristã na batalha de Prevenza), a qual, na instrução ao embaixador, D. João III demonstrava a importância de que sempre lhe fosse escrito sobre "todas as novas que o mundo der":

Posto isto me despachareis correio avizandome vossa chegada e de tudo o que houverdes passado, e la souberdes de que vos prazera que eu deva de ser avizado e assi terey cuidado sempre de fazer pelo tempo adiante, e muy particularmente trabalharey de saber todas as novas que o mundo der, especialmente das cousas publicas, que tocar ao Universal de toda a

24 D. MARTinho De PORTUGAL. "Carta a Pero de Alcáçovas Carneiro de 30 dez. 1526". In: CDP. Vol. 2, p. 282.

25 D. MANUEL. “Carta a D. Miguel da Silva de 29 mai. I5I8”. In: CDP. Vol. 2, p. II. Volante é o "não fixo", como o "campo volante", pequena tropa do exército com armas ligeiras e com pouca artilharia, que movimenta com maior velocidade no campo de batalha a fim de dar avisos e socorros. BLUTEAU, Raphael. Op. Cit., Vol. 8, s. v. "Volante”, p. 566.

26 D. JOÃO III. “Carta a João da Silveira de 5 fev. I522”. In: VENTURA, Margarida Garcez. Op. Cit, p. 146. 


\section{REVISTA ANGELUS NOVUS}

Cristandade, porque estas mais que todas tocão a mi e ao meu serviço, de que eu confio que em todas as couzas e em todas as horas vos tereys aquelle cuidado e lembrança que deveis. ${ }^{27}$

Em Roma, D. João III também propôs a ampliação das vias de comunicação, tendo a sua relação com o imperador Carlos V, um fator de incentivo aos embaixadores. Escrevendo para o embaixador Pedro de Mascarenhas no ano de 1538 , D. João III apontava que as possibilidades à troca de cartas eram diversas e o embaixador precisava manter as vias de comunicação sempre em movimento. Segundo o monarca, Pedro de Mascarenhas podia enviar cartas por diferentes rotas de transporte, como as gerenciadas pelo imperador, que dado a proximidade geográfica e a ligação das cortes após os casamentos cruzados, ${ }^{28}$ se tornava um caminho viável e de confiança do monarca para circular suas informações. Além do mais, o embaixador também poderia utilizar das rotas do Correio-mor, definidas juntamente com os navegadores portugueses e outros comerciantes que chegavam ao reino a todo instante:

Muyto folgarey de me screverdes, por todas as vias que vos forem possíveis, asy de coreos do emperador, e por via da corte da emperatriz [Isabel de Portugal], endereçando as cartas a antonio homem, meu capelam, que nela pera este efeyto mando andar, como por via de mercadores, e de qualquer outra que se oferecer, porque os tempos sam de calidade e os negocios do mundo tamanhos, que por todalas vias nam podem deixar de a mym toquar muyto particularmente. ${ }^{29}$

Desse modo, o rei buscava expandir a sua rede de informações, incentivando que seus embaixadores o escrevessem, pois, segundo D. João III, haveria uma alteração no tempo com a chegada do imperador à Península Ibérica, que os embaixadores deveriam aproveitar. Ter a carta assegurada por emissários do Sacro Império era uma garantia que D. João III via como exclusiva de seu reinado. ${ }^{30} \mathrm{~A}$ partir dela, o monarca tinha a possibilidade de reter informações de Roma e poder se comunicar com o papa e com

27 "Memórias e documentos sobre a política externa portuguesa entre 1515 e 1568 ". Biblioteca Nacional de Portugal. Códice 886, folha 415. (Adiante abreviatura BNP).

28 D. João III casou com a irmã menor de Carlos V, Catarina da Áustria, em is25 e o imperador casouse com a infanta Isabel de Portugal em I526. Os contratos de casamento foram firmados em Burgos, em cinco de julho de 1524, diante de Pero Correia e João de Faria, que representavam D. João III e Hernando de Veiga, comendador da Ordem São Tiago em Castela, e Mercurino de Gattinara, chanceler do imperador. Sobre as negociações para os casamentos, ver em: BRAGA, Isabel Mendes Drumond, Um Espaço, Duas Monarquias (Interrelações na Península Ibérica no Tempo de Carlos $V)$. Lisboa: Centro de Estudos Históricos da Universidade Nova de Lisboa; Hugin Editores, 20oI, pp. 87-IOI.

29 D. JOÃO III. “Carta a Pedro de Mascarenhas de [?] I538”. In: CDP. Vol. 3, p. 446.

30 Vale lembrar, que antes em I45I, Leonor, filha de D. Duarte e irmã do rei D. Afonso V, casou-se com o imperador Frederico III do Sacro Império Romano Germânico, mas esses viveram na corte de Viena. LIMA, Douglas Mota Xavier de. A Diplomacia Portuguesa no reinado de D. Afonso V (I448-I48I). Tese de Doutorado. Niterói/RJ: Universidade Federal Fluminense, 2016, pp. 219-240.

$\mathrm{I} 64 \cdot$ ano XI, n. I6, 2020 • ISSN 2I79-5487 
seu embaixador com menos risco da mensagem se perder no caminho, seja pelo extravio da correspondência, ou pela morte do mensageiro. ${ }^{3 \mathrm{I}}$ Para além disso, diversos caminhos para estabelecer a ligação com a embaixada, como por via de rotas comerciais, não exclusivamente portuguesas, como venezianas ${ }^{32}$ ou flamengas, ${ }^{33}$ ou ainda por via das ordens religiosas, era mais uma das possibilidades ao embaixador. ${ }^{34}$ No entanto, vale destacar que os mensageiros régios não levavam apenas cartas entre os representantes da Coroa. Durante a Dieta de Augsburgo de I530, os emissários de D. João III que acompanhavam Pedro de Mascarenhas, talvez no percurso até Portugal, tenham passado por Freiburgo e levado cartas de Philippe Melancthon (teólogo da delegação da Saxônia), a Erasmo de Roterdã. Como Erasmo aponta, após receber uma carta de dois de Agosto daquele ano: "I paid the Portuguese young man generously out of my own pocket". 35

Assim, D. João III demonstra a necessidade do rei de estar consciente acerca de todas as notícias que circulavam. Nada podia passar despercebido pelos embaixadores, cabendo informar o soberano de todas as maneiras, vias e possibilidades que se vinham a afirmar. Com efeito, os embaixadores residentes eram instruídos pelo rei, antes mesmo da sua partida, que mantê-lo informado, estava entre seus principais deveres.

3I Os mensageiros eram uma posição que recebia diversos benefícios, como Pedro Luís, cavaleiro de D. João III que recebeu uma tença de doze mil e setecentos e oitenta reais após trazer "boas novas" da saúde da imperatriz Isabel de Portugal em 24 de setembro de 1533 e Antônio Ribeiro que após levar cartas do rei ao imperador, em novembro de 1532, lhe foi pedido por via do embaixador Álvaro Mendes de Vasconcelos, o ofício de Correio-mor. ANTT, Chancelaria de D. João III. Doações. Livro 7, folha 26; ANTT, Corpo Cronológico. Parte I, maço 5o, doc. 36. (Adiante abreviatura $C C$ ). Ver também em: VITERBO, Francisco de Sousa. "Mensageiros Reais". In: SERRÃO, Joaquim Verissimo et. alli. Archivo Historico Portuguez. 2 ed. Vol. I. Santarém/PT: Câmara Municipal de Santarém, 200I, pp. I09-II5; I82-I84.

32 Ver, por exemplo, privilégios concedidos por D. João III aos comerciantes venezianos, de Nápoles e da Sicília no ano de 1533, em: REGO, António da Silva (org.). As Gavetas da Torre do Tombo. Vol. I. Lisboa: Centro de Estudos Históricos Ultramarinos, 1960, pp. 875-890.

33 D. João III no ano de I524, por exemplo, ampliou o privilégio das famílias flamengas Estrelins e Hanses concedidos por D. Manuel, de comercializarem tecidos de seda e especiarias com os comerciantes de Lisboa e noutros portos portugueses, com isenção fiscal e liberdade de usarem as balanças e os armazéns da Alfândega. Mas, a partir da instauração do tribunal da Inquisição na década de 1540, muitos comerciantes foram confiscados no reino, por suspeitas de luteranismo. ANTT, Chancelaria de D. João III. Doações. Livro II, folha I49. Ver também em: DENUCÉ, Jean Louis-Paul. "Privilèges commerciaux accordés par les rois de Portugal aux Flamands et aux Allemands (XV et XVI Siècles)”. In: SERRÃO, Joaquim Verissimo et. alli. Op. Cit., Vol. 7, pp. 310319; 377-392.

34 Sobre as ordens religiosas: PALOMO, Federico. "La Memoria del Mundo: Clero, Erudición y Cultura Escrita en el Mundo Ibérico (Siglos XVI-XVIII)”. Cuadernos de Historia Moderna. XIII, 20I4, pp. II-26.

35 FANTAZZI, Charles. The Correspondence of Erasmus. (August I530 - March I53I). Toronto/CA: University of Toronto Press, 2016, p. 4. 


\section{REVISTA ANGELUS NOVUS}

Como é ordenado a D. Martinho de Portugal antes de ir a Roma: "Vós sempre me auisareis do que sera necessario, quanto com mais brevidade quanto mais me seruireis". ${ }^{36}$ E a João da Silveira, quando partia para a França: "E estes recados vos trabalha por nos emviardes pelas mais curtas vyas que vos for posivel e asy cobrados como parecer que conveem". ${ }^{37}$ Mesmo os monarcas europeus eram requisitados a escreverem, Lope Hurtado de Mendonza, embaixador na corte portuguesa, pediu a Carlos V que não se escusasse de enviar correios ao rei: "Vuestra Magestad lo escriva aca, que es cosa de que se huelgan”.$^{38} \mathrm{~A}$ função de informar estava intimamente ligada à atividade do governo, ademais, a capacidade de ser um correspondente régio, demonstrava um estreito vínculo com o governante, criando laços de zelo e lealdade, que para o embaixador eram oportunidades de recompensas futuras. ${ }^{39} \mathrm{E}$ para a Coroa, o interesse não era saber tudo minuciosamente, mas manter a possibilidade de comunicação contínua, visto que a própria ação de recolher informações era uma forma de legitimar o domínio perante aos súditos..$^{\circ}$

Antes das Gazzetas e dos Mercúrios, periódicos que tiveram maior dimensão na Península Ibérica no século XVII, a atividade dos diplomatas já permitia que variadas notícias circulassem pelos reinos. ${ }^{41}$ Essas muitas vezes eram dadas por incertas, não passavam de boatos ou "novas falsas", mas eram igualmente requisitadas pelo soberano. Brás Neto, que esteve na Cúria romana entre 1530 e 1532, soube por via do embaixador de Veneza que o sultão Solimão I reuniria seus soldados com a armada de Khair-ed-Din (apelidado de Barbarrossa), para invadirem Ancona, cidade que pertencia aos domínios

36 D. JOÃO III. “Despachos que leuou D. Martinho de Portugal de 20 mai. 1532”. In: CDP. Vol. 2, p. 366

37 D. JOÃO III. “Carta a João da Silveira de 5 fev. I522”. In: VENTURA, Margarida Garcez. Op. Cit., p. I50.

38 LOPE HURTADO DE MENDONZA. “Carta a Carlos V de 28 abr. 1528 ”. In: VIAUDE, Aude. Op. Cit., p. 267.

39 CARDIM, Pedro. “Amor e Amizade na cultura política dos séculos XVI e XVII”. Lusitania Sacra. 2a Série, II, 1999, p. 45. Ver também em: MENDES, Carolina Garcia. "O Lugar Social da Correspondência no século XVII: As Cartas do Governador Geral Francisco Barreto (1657-1663)”. In: CONCEIÇÃO, Adriana Angelita da; MEIRELLES, Juliana Gesueli (orgs.). Cultura escrita em debate: reflexões sobre o império português na América - séculos XVI a XIX. Jundiaí/SP: Paco, 20I8, pp. 63-88. Sobre as recompensas, mercês e privilégios concedidos pela a Coroa: RICUPERO, Rodrigo. Op. Cit, pp. 37-6o.

40 A ideia é levantada por Arndt Brendecke a respeito das redes de informações do governo dos Habsburgo nos domínios da América: BRENDECKE, Arndt. Imperio e Información. Funciones del saber en el dominio colonial español. Madrid: Iberoamericana; Frankfurt: Vervuert, 20ı6, pp. 253-305.

4I MEGIANI, Ana Paula Torres. "Escritos breves para circular. Relações, notícias e avisos durante a Alta Idade Moderna (sécs. XV-XVII)”. Varia História, Belo Horizonte. Vol. 35, № 68, 2019 , p. 557.

I66 • ano XI, n. I6, 2020 • ISSN 2179-5487 
papais na Península Itálica. ${ }^{42}$ Segundo o embaixador, a armada otomana compunha uma força que atemorizava por uma nova invasão em Roma (saqueada anos antes pelas tropas de Carlos V), pois acreditava que muitas pessoas de Ancona buscariam se refugiar nos muros da cidade: "E se a armada he tam grossa como dizem, nom seraa muito sayrem em hostias em terra, e correrem ate as portas desta cidade, e ainda entrarem dentro, porque eu nom veijo quem lha possa defender". ${ }^{43}$ A notícia, entretanto, era incerta, Brás desconfiava da existência de uma armada otomana enquanto havia notícias da movimentação de soldados do sultão nas fronteiras do reino da Hungria. O melhor informante no momento, seria o embaixador na corte imperial, Pedro de Mascarenhas, visto que esse estava com Carlos V em Ratisbona, justamente em uma campanha militar contra Solimão I. Mas, como embaixador residente, Brás Neto reconhecia que precisava enviar a informação ao monarca, pois: "todavia lho quis escreuer porque asy mo tem Vossa Alteza mandado". ${ }^{44}$

Pedro de Mascarenhas não confirmava a informação, mas igualmente duvidava da existência da armada otomana, além de expressar temor pelas intenções de Veneza e de Francisco I durante a campanha do imperador: "De França non ha ate agora nova que aas crara faça nenhuma demostraçam contra ho Emperador, mas ha muitas mostras de o desejar, parece que spera ver como socede esta iornada do Turco. Entretanto no deixa as escondidas de tramar ho que pode". ${ }^{45}$ Como embaixador na corte imperial, é possível que Pedro de Mascarenhas tivesse conhecimento da carta de Rodrigo Ninho, embaixador de Carlos V na signoria de Veneza, que acreditava que as informações sobre a armada otomana era uma farsa dos venezianos, aliados dos franceses, sob o pretexto de invadirem o ducado de Milão e Florença, enquanto as armadas do imperador e do papa iriam erroneamente a Ancona. "There is no preparation for war there, because of the diversity of news about the Turk" - dizia Rodrigo Ninho, a respeito de Milão e Florença: "It is publicly said that the day Francis knows that war is begun between the

42 Khzir ou Khair-ed-Din (o protetor da fé), junto a seu irmão Aruj, saquearam portos mediterrânicos até a costa sul de Castela e no norte da África, conhecidos por fundarem o sultanato de Argel em i5i6. Os dois foram apelidados de Barbarrosa, ou "Barba Roxa", devido a corruptela de baba Aruj, pai Aruj. Khzir faleceu em I546, após ter tido sucessos em campanhas contra as armadas cristãs, como na batalha de Prevenza de 1538 e a invasão as ilhas Baleares em 1529. Ver em: GÜRKAN, Emrah Safa. Espionage in the I6th Century Mediterranean: Secret Diplomacy, Mediterranean go-betweens and the Ottoman Habsburg Rivalry. Tese de Doutorado. Washington: Georgetown University, 2012, pp. 345-431.

43 BRAZ NETO. “Carta a D. João III de 6 jul. is32”. In: CDP. Vol. 2, p. 403.

44 Ibidem, p. 403.

45 PEDRO DE MASCARENHAS. “Carta a D. João III de i3 jul. I532”. In: $A N T T, C C$. Parte i, maço 49, doc. 42 . 


\section{REVISTA ANGELUS NOVUS}

Emperor and the Turk he will march to Italy". ${ }^{6}$ Foi apenas dois anos depois que houve notícias de saques na costa da Península Itálica, em Nápoles, quando Khair-ed-Din (agora comandante da armada do sultão), comandava uma invasão a Túnis, no norte da África. Mas como o trajeto da armada era desconhecido, o novo embaixador Henrique de Meneses, ainda relatava o estremo receio de um novo saque em Roma:

E apos isto asomou aquy, antre napoles e Roma, barba Roxa com noventa ate cem gales e fustas, e saquejarão huma uilla de napoles daquy sessenta milhas. Foy, senhor, aquy tamanho o medo que nom sabião onde se meter, e auyão medo de cyncuo ou seis myl homens de mar vyrem outra vez saquejar Roma; e ainda nam estão muito fora deste Receo, que o barba Roxa passou pera baixo: nom sabemos que fara. ${ }^{47}$

Mas não só de informações sobre as guerras na Europa marcava o conteúdo das cartas. Dentre as principais informações que circulavam, os assuntos estratégicos do governo, "as cousas publicas", eram indispensáveis para a Coroa. As nomeações eclesiásticas, as atividades comerciais das especiarias indianas e artigos de luxo do Oriente (principais produtos de exportação no momento) tinham lugar de destaque e eram altamente requisitadas. Nas instruções a Pedro de Mascarenhas, quando foi residir na corte de Carlos V em I530, D. João III acentuava que o embaixador deveria estar sempre atento com a "disposição do imperador" para com todos os negócios com Portugal. Mas, sobretudo, por Pedro de Mascarenhas ter uma posição privilegiada na corte, ele teria importantes informações da situação de Flandres, no ducado da Borgonha, a principal rota das especiarias do Oriente e um dos territórios de domínio do imperador: "Todas as vezes que souberdes que para ali vem correios ou outros mensageiros que se puderem oferecer a miude, e, se vos parecer que alguns são de qualidade para mas fazerdes a saber por correio proprio e em diligencia, assim o fareis". ${ }^{8}$ Um desses correios chegou em fevereiro de I533. Quando o vedor da fazenda, Antônio de Ataíde e o mercador cristão-novo Diogo Mendes, preparavam o

46 RODRIGO NINHO. “Carta a Carlos V de 5 jul. I532”. In: GAIRDNER, James. Letters and Papers, foreign and domestic of the reign of Henry VIII. Vol. 5. London: Longsmans, Green, Reader \& Dyer, I880, p. 5II.

47 HENRIQUE DE MENESES. “Carta a D. João III de 19 ago.I534”. In: CDP. Vol. 3, p. 85. Segundo Ermrah Safa Gürkan, as notícias sobre a invasão a Península Itálica vieram não dos franceses, mas de Alvize Ludovico Gritti, filho do Doge de Veneza, Andrea Gritti, que mantinha contínua ligação comercial e militar com os vizires de Solimão I. GÜRKAN, Emrah Safa. Op. Cit., p. 375. Sobre as disseminações de notícias por embaixadores e periódicos de Veneza: DE VIVO, Filippo. "Microhistories of long-distance information: Space, Movement and Agency in the Early Modern News". Past and Present. Suplement I4, 2019, pp. 179-214.

48 D. JOÃO III. "Instruções a Pedro de Mascarenhas de 23 nov. I529". In: ANDRADA, Ernesto de Campos de. Relações de Pero de Alcáçova Carneiro, Conde de Idanba, do tempo que êle e seu pai, António Carneiro, serviram de secretários (I5IS a I568). Lisboa: Imprensa Nacional de Lisboa, I937, p. 76.

I68 • ano XI, n. I6, $2020 \cdot \mathrm{ISSN} 2179-5487$ 
BARROSO • "Comunicação política e diplomática no reinado de D. João III" carregamento de pimenta e cravo para Flandres, D. João III escreveu com imediata urgência, pedindo que moderassem a quantidade das mercadorias, pois tinha uma importante informação da corte imperial:

Conde Amiguo. Eu ellRey, vos envio muyto saudar. Dom Pedro Mazcarenhas me escreveo, que lhe parecia que, enquanto Diogo Mendez, irmão de Francisco Mendez, nom he acabado livrar dos casos que em Frandes lhe foram postos, nom devia de tratar tam grossamente como d'antes fazia, nem lhe devia de ir tanta fazenda ha nau; e por quam incertas sam as cousas d'aquelas partes, me parece bom aviso o de dom Pedro. ${ }^{49}$

Os embaixadores, também reiteravam o pedido que o rei mantivesse a circularidade do correio volante. As cartas do monarca serviam como direcionamento as suas funções na Cúria romana e para tanto, quando não havia resposta, os embaixadores se colocavam como esquecidos, abandonados ou muitas vezes vítimas de exílio. ${ }^{\text {50 }}$ É o que diz Pedro de Mascarenhas ao lembrar D. João III que se ele deseja ser bem servido, necessitava escrever o mais ligeiramente possível: "Vossa Alteza se resolva no que for mais servido, e comforme a iso me mande sua comyção, e quanto mais cedo ser servido seraa”. ${ }^{\text {si }}$ De outra forma, Brás Neto demonstrou inquietação frente ao monarca que não enviava correios e já estava com recursos financeiros escassos em Roma, pedindo que o rei o liberasse dos seus serviços e o desce licença para retornar a Portugal:

Somente beijarey as mãos de Vosa Alteza [quando] responder me o que ha por bem que faça acerca da minha estada qua, e lembrar se que nom tenho renda nem fazenda com que possa sofrir esta carega, e por isso me dar licença pera me hir por me nom ver em tanta vergonha..$^{25}$

Henrique de Meneses lembrava que não apenas era importante que o escrevesse, mas que D. João III também sempre enviasse suas cartas ao papa e aos cardeais de Roma, de forma a agradecer aos serviços prestados ou mesmo fazer novos pedidos na Cúria. Segundo o embaixador, o envio da carta ao cardeal Santiquatro, por exemplo, era necessária também para a própria realização da sua função em Roma: "E Vossa Alteza escreua lhe e agradeça lhe muito canto ele se mete e que meter nas cousas de uoso serviço; e sem esta carta de Vossa Alteza verdadeiramente nom ousarey eu de estar nem

49 D. JOÃO III. “Carta a António de Ataíde de I3 fev. I533”. In: FORD, Jeremiah Denis Matthias. Letters of John III King of Portugal (I52I-I557). Cambridge: Harvard University Press, I93I, p. 96.

so D. Miguel da Silva, por exemplo, chamava a embaixada de "cativeiro", pela falta de respostas do rei. D. MIGUEL DA SILVA. “Carta a D. João III de 25 mai. 1523 ”. In: CDP. Vol. 2, p. I52. Para outros exemplos, ver em: CARDIM, Pedro. "Embaixadores e representantes diplomáticos da Coroa portuguesa no século XVII”. Cultura, Série 2, № 15, 2002, p. 53. 


\section{REVISTA ANGELUS NOVUS}

parar em Roma". 53 Em comum, os embaixadores reclamavam do atraso no envio das cartas, demonstraram estar sempre preocupados com o tardar das notícias e procuraram incentivar que D. João III enviasse correios aos embaixadores e outros nobres no papado. D. Miguel da Silva, por exemplo, preferiu recorrer ao secretário Antônio Carneiro, pois: "Bem sey que se nam esquece vossa merce de mim, mas esquecendo-se elRey nam poso deixar de lhe lembrar que o que faz por mim faz por si mesmo, e por seu proprio seruiço". ${ }^{54} \mathrm{O}$ mesmo ainda pode-se dizer de Lope Hurtado de Mendonza, que como um estrangeiro na corte portuguesa, indicava-se ao imperador Carlos $\mathrm{V}$, a morosidade de D. João III com seus pedidos: "Porque asy lo es la condinción del Rey más que de ninguna persona que yo aya visto”, e além do mais, Lope havia verificado que os negócios em Portugal eram sempre prejudicados pela falta de objetividade do monarca: "dizen los suyos que, aunque le fuese a perder todo quanto tiene, no yria más de priesa y asy sus cosas entiendo que las tiene muy enballestadas y de mala manera porque nunca acaba nada y nunca haze sino negociar".ss

Embora houvesse atraso ou perca de mensagens, era assegurado que haveria um correio ordinário mensal, que permitiria a circulação de informações de forma eficiente e segura. ${ }^{56}$ Segundo o monarca, os embaixadores podiam inclusive sobressair ao envio ordinário de cartas e enviarem informações em outros momentos, quando a necessidade ou a urgência surgirem:

A maneira que quereis saber que tereis em me enuiar vossas cartas, sempre pelos correios ordinarios de cada mes me escreuey o que então ouuer pera me escreuerdes, e quando ouuer necessidade fazerdes correio proprio, porque cumpre assi a meu serviço, o farei, e adressarei vossos maços das cartas pera mi a quem vos parecer que me as podera dar com aquella dilligencia que cumprir a meu serviço. ${ }^{57}$

Há de se destacar, que com a realização do Concílio de Trento, a partir de 1546, os cardeais e grande número dos clérigos de Roma vão para o concílio, fazendo com que

53 HENRIQUE DE MENESES. “Carta a D. João III de io abr. 1534”. In: CDP. Vol. 3, p. 8I. Santiquatro, cardeal Quatro Sanctus Coroado, era um dos quatro principais da Cúria e um dos favoritos para a sucessão do papado. Além do mais, era considerado o cardeal protetor de Portugal. Ver em: CASTRO, José de. O Cardeal Nacional. Lisboa: Agência Geral das Colónias, 1943.

54 D. MIGUEL DA SILVA. "Carta a Antônio Carneiro de 20 mai. I523”. In: CDP. Vol. 2, p. isı.

55 LOPE HURTADO DE MENDONZA. “Carta a Carlos V de 19 jan. I529”. In: VIAUDE, Aude. Op. Cit., p. 329.

56 Em analogia, Arndt Brendecke chama atenção para o setting do domínio de Carlos V e Felipe II que permitia diversas possibilidades de escrita aos administradores das conquistas na América, posto que se instituía vias de comunicação direta e alternativa que asseguravam o envio de despachos, cartas, reclamações, além de denúncias entre esses para a Coroa. BRENDECKE, Arndt. Op. Cit., pp. 253-305.

57 D. JOÃO III. “Despachos que leuou D. Martinho de Portugal de 20 mai. 1532”. In: CDP. Vol. 2, p. 380.

I70 • ano XI, n. I6, $2020 \cdot \mathrm{ISSN} 2179-5487$ 
muitas das comunicações passem necessariamente pela região norte da Península Itálica. Baltasar de Faria, embaixador em Roma durante i542 e I55I, notou que com esse esvaziamento da Cúria: "Cada dia se partem d’aqui prelados pera Trento. Sua Santidade manda agora parte dos cantores da sua capella e de todos os mais officiaes". ${ }^{88}$ Porém, foi quando houve retorno das atividades do Concílio, após a suspensão entre os anos de I548 e I55I, e com o aumento das incursões de armadas otomanas, que o envio de informações pela via do Mediterrâneo teve um dos momentos mais críticos. Como exemplifica o embaixador e comendador-mor da ordem de Cristo, Afonso de Lencastre:

Os dias passados se perderão as cartas todas que forão por via de Genoa em companhia de hum despacho do emperador que hia para o príncipe [D João] porque a fusta que o levava ha assaltou hua de turcos e a de Genoa ha aferrou e andando as cotiladas parece que antes que se ajuntassem derão hua mosquetada polo lume da agoa a genoesa e asi tendo a genoesa quase rendido a turchesa se foi ao fundo sem se salvar ninguém. 59

No entanto, não era apenas em Roma, que se indicava insegurança nos correios. $\mathrm{Na}$ embaixada francesa, João da Silveira relatava grande dificuldade no envio de suas cartas, principalmente, devido as guerras envolvendo Francisco I e Carlos V. Como observou o cronista Antonio de Castillo, mesmo o envio de correios ordinários estava comprometido, pois: "pello perigo dos correios [João da Silveira] não podia avisar el Rej dom Joam das cousas de França”. ${ }^{60} \mathrm{O}$ tempo de trajeto normalmente ultrapassava o previsto e o mensageiro nem sempre era de confiança. Para resolver essas dificuldades, João da Silveira buscou firmar um emissário com o rei que só receberia seu onerário quando entregasse a carta, seja a D. João III ou ao embaixador. Ademais, quando a informação era de vital importância, ele duplicava o envio da missiva, por um segundo emissário por terra, enquanto que o correio ordinário ia por mar. Em primeiro momento, a escolha foi importante por assegurar informaçóes da chegada de corsários no Brasil, como o florentino Giovanni da Verrazano que tomou grande quantidade de pau-brasil e havia regressado em setembro de 1527 a França. ${ }^{61}$ Entretanto, D. João III ponderou sobre a escolha do embaixador, além dos gastos terem sido acima do previsto, o caminho por terra era demorado e perigoso, principalmente, para um emissário

BALTASAR DE FARIA. “Carta a D. João III de I2 jan. I546”. In: CDP. Vol. 6, p. 2. AFONSO DE LENCASTRE. “Carta a D. João III de 23 ago. 1553”. In: CDP. Vol. 7, p. 249.

6o CASTILLO, Antonio de. "Vida del Rey don Joam III". In: SERRÃO, Joaquim Veríssimo. Figuras $e$ Caminhos do Renascimento Português. Lisboa: Imprensa Nacional-Casa da Moeda, 1994, p. 268.

6I JOÃO DA SILVEIRA. “Carta a D. João III de 24 dez. I527”. In: VENTURA, Margarida Garcez. Op. Cit., p. 168. Sobre Giovanni da Verrazano, ver em: GRAVIER, Gabriel. Les voyages de Giovanni Verrazano sur les côtes d'Amérique. Rouen/FR: Cagniard, I898. Disponível em: «https://gallica.bnf.fr/ark:/12148/bpt6k57080072». Acesso em 20 jun. 2020. 


\section{REVISTA ANGELUS NOVUS}

francês que atravessava os territórios do imperador Carlos $\mathrm{V}$ quando esse estava em guerra contra a França:

Este mensageiro que enviastes com vossa carta feita a xxix de Março pasado chegou a esta cidade a xij de Mayo, e disse que nam foy posyvel fazer mayor diligemcia, e assy que havia d'aver por seu caminho vynte escudos. E ca lhe mandey pagar vimte cruzados e mais os dias de demora que fez atee sua partida. Pello comcerto que com elle fezestes veres se os mereceo, e asy como com ele comcertastes faze com elle conta. E vay paguo da torna viagem, a qual faz por maar por nam se atrever a pasar por terra. ${ }^{62}$

Em suma, o dever de informar continuamente ao rei, possibilitou a abertura de canais de comunicação entre o reino e as embaixadas das mais diferentes vias. Duplicar ou até mesmo triplicar as cartas, era uma forma segura de envio de informações, mesmo que tomasse tempo maior que o esperado. ${ }^{63}$ Ademais, vale lembrar, que ao repassarem as informações, os embaixadores teciam diversos comentários e refletiam sobre qual a posição devia ser tomada pelo monarca. Ou seja, buscaram mover as decisões no reino, não replicando as mensagens sem uma primeira análise, mas indicando alternativas para que fossem votadas no Conselho. Utilizar de diferentes vias de comunicação, como comerciantes, correio régio e emissários de outras cortes foi importante para a Coroa portuguesa tomar conhecimento das ações dos seus vizinho na Europa, assim como, permitiu aos embaixadores adentrarem em suas carreiras diplomáticas e nos serviços ao rei, recebendo grandes compensações ao término da realização de suas funções. Porém, o aumento das diferentes possibilidades para o envio das cartas também permitia que as informaçôes pudessem ser interceptadas por inimigos da corte. Por isso, averiguar as formas de se assegurar o envio das mensagens e impedir que as informações circulassem é o tema do tópico seguinte.

62 D. JOÃO III. "Carta a João da Silveira de 30 jun. I530". In: VENTURA, Margarida Garcez. Op. Cit., p. I83. Levando em conta que I cruzado equivalia a 400 reais e r escudo a 470 reais, D. João III pagou I.400 reais a menos do que foi pedido pelo mensageiro, fora os dias a mais antes da partida. Os dados da conversão são do projeto Prices, Wages and Rents in Portugal I3oo-Igro do Instituto de Ciências Sociais da Universidade de Lisboa. Disponível em: «http://pwr-portugal.ics.ul.pt/». Acesso em I4 abr. 2020 .

63 Lope Hurtado de Mendonça escrevendo para a imperatriz Isabel de Portugal, informou que buscaria um terceiro mensageiro para enviar suas cartas, pois suspeitava que um dos outros estava a serviço do embaixador francês Honorato de Caix: "Con otro mensagero escrivire lo que después he sabido que es más causa para escusar de dar parte al doliente del negocio y menos al que yo escrevi a Vuestra Magestad porque d'él se tiene aca sospecha por la otra parte que ha seydo mal terçero". LOPE HURTADO DE MENDONZA. "Carta a Isabel de Portugal de 26 mai. 1530". In: VIAUDE, Aude. Op. Cit., p. 417.

I72 • ano XI, n. I6, 2020 • ISSN 2I79-5487 
BARROSO • "Comunicação política e diplomática no reinado de D. João III”

\section{Práticas de escrita e mensagens secretas}

Se o embaixador tinha que estar atento aos caminhos de comunicação com o monarca, de igual maneira, ele deveria se preocupar com a escrita das suas correspondências. Nas recomendações de D. João III, o embaixador devia ter em mente quando ele próprio deve escrever e quando a carta deve ser redigida por um escrivão. A proposta era dar uma hierarquia à notícia, escrita pelas mãos do embaixador, a Coroa poderia reconhecer o grau de importância que a carta teria. Ao mesmo tempo, servia para orientar os embaixadores, como D. Martinho de Portugal, que não deveria confiar nem mesmo em seu escrivão: "por uossa mao escreverey aquellas couzas que forão assi secretas que nam as deuaes confiar de ninguem, e as outras me escreuas por mão d'outrem, e ao cumprir resposta uos mandarey responder assi como vir que cumpre a meu serviço". ${ }^{64}$

A escrita pelo próprio punho, como Fernando Bouza comenta: "cabe interpretar los renglones como una forma de respeto y deferencia y, por tanto, llegar a considerarlos como magnitud mensurable de la distinción que se deseaba mostrar" ${ }^{65} \mathrm{O}$ manuscrito se inseria em uma ordem dinâmica própria, ou seja, seu significado transcendia o conteúdo da mensagem e cumpria desde funções de privacidade e sociabilidade, quanto instrumento de poder sobrenatural, de cura e proteção. O rei que era visto como possuidor de poderes taumatúrgicos, podia expressá-los também por suas letras, permitindo que o papel desse um conforto e segurança a quem o obtinha. ${ }^{66} \mathrm{Em}$ uma anônima carta endereçada a D. João III, observa-se:

Senhor. Espero em Nosso Senhor que as acupações que tenho por serem em servir Vossa Alteza abastem pera me curar esta doença, e se asy for, guardarey a carta em que, por me fazer mercê e me dar saude, diz que quer saber como ca estou, pera curar sobre mayor quãdo a tiver. Louvores a Deus, ca estou mylhor do que estyve, e não me pode parecer que estyve mal, porque em quãto poso servyr Vossa Alteza sempre cuydo que estou bem. Nosso Senhor guarde e acrecente a vyda e Real estado de Vossa Alteza. De Lysboa, a V de março de $1551 .{ }^{67}$

64 D. JOÃO III. "Despachos que levou D. Martinho de Portugal de 20 mai. I532". In: CDP. Vol. 2, p. $38 \mathrm{I}$.

65 BOUZA, Fernando. "Escribir a corazón abierto: Emoción intención e expresión del ánimo en la escritura de los siglos XVI y XVII”. Varia História, Belo Horizonte. Vol. 35, № 68, 2019, p. 5I5. Ver também em: Idem. Corre Manuscrito. Una historia cultural del Siglo de Oro. Madrid: Marcial Pons, 20oI, p. 98.

66 Sobre a origem dos poderes taumatúrgicos dos reis, ver em: $\mathrm{BLOCH}$, Marc. Os reis taumaturgos. O caráter sobrenatural do poder régio. França e Inglaterra. São Paulo: Companhia das Letras, 20I8, pp. 68-87.

67 ANÔNIMO. "Carta a D. João III de 5 mar. I5sI". In: FORD, Jeremiah Denis Matthias; MOFFATT, Lucius Gaston. Letters of the Court of John III King of Portugal. Cambridge: Harvard University Press, 1933, p. 169. 


\section{REVISTA ANGELUS NOVUS}

Em Roma, o rei D. Manuel propunha moderar o envio de cartas aos cardeais, bem como ao papa, acreditava que uma mensagem passada oralmente pelo embaixador teria um efeito muito mais desejado. D. Miguel da Silva, entretanto, discordava. Em julho de I517, após a eleição do infante D. Afonso ao Colégio de Cardeais, o embaixador lembrou do "contentamento" e da "honra" que o rei daria ao papa e aos cardeais, caso lhe agradecessem por carta escrita pelo punho do monarca: "He necessario que escreua Vossa Alteza carta de agradecimentos ao Collegio todo, [na carta ao papa] me paresce que deue viir, mays ainda a meu fraco juízo deuia de ser da mãoo de Vossa Alteza, por dar este contentamento ao papa, e allem disso hauello ha por grande honra". ${ }^{68}$ Contudo, o rei avisou que seguiria o conselho do embaixador, mas enviaria correspondência apenas aos cardeais, ao papa era necessário que o embaixador o agradecesse presencialmente: "E de nossa parte o Remereceay ao santo padre e lhe beijay seus santos pes, Remerceando lho com todas as boas palavras de ystymaçam, que se Requere em semelhante graça”. ${ }^{69}$

Assim, determinados assuntos eram preferíveis não se discutir, não pelo conteúdo das discussões, mas por ser mais importante que fossem levados de outra maneira que não pela escrita. ${ }^{\circ}$ Nesse ponto, a transmissão oral tinha naturalmente o objetivo de não dar a informação por escrito, por poder comprometer quem a enviava. $\mathrm{O}$ embaixador cumpria a função de ser o intermediário da mensagem, visto que a carta funcionava como ponto inicial da informação, que autorizaria as palavras do embaixador. Exemplo disso, é a carta de crença de D. Manuel, que ao fazer o primeiro pedido da Inquisição em I515, não citava quais os objetivos da audiência do embaixador D. Miguel da Silva com o papa Leão X, apenas pedia que: "Sopricamos por mercee a Vossa Santidade que o queyra ouvir e em tudo lhe dar inteira fee e crença e em muy singular mercee o receberemos de Vossa Santidade muito santo in Cristo padre e muyto bem aventurado Senhor". ${ }^{7}$ Nas cartas do embaixador D. Miguel da Silva, observa-se uma considerável preocupação em saber o que se pode ou não escrever, mas com o intuito de não se revelarem segredos. Ao fim do ano de I522, por exemplo, quando os exércitos otomanos tomavam a ilha de Rodes no mar Egeu e seguiam em direção a região sul da Grécia, D.

D. MIGUEL DA SILVA. “Carta a D. Manuel de or jul. i517”. In: CDP. Vol. i, p. 475.

69 D. MANUEL. "Carta a D. Miguel da Silva de 04 ago. I5I7". In: CDP. Vol. I, p. 480.

70 Para esse tema, ver em: CARDIM, Pedro. "Nem tudo se pode escrever'. Correspondencia diplomática e información 'política' en Portugal durante el siglo XVII". Cuadernos de Historia Moderna, IV, 2005, pp. 95-I28; GÓMEZ, Antonio Castillo. "Del tractado a la practica. La escritura epistolar en los siglos XVI y XVII". VI Congreso Internacional de Historia de la Cultura Escrita. Vol. I, 2002, pp. 79-107. 
Miguel da Silva reiterava o pedido de licença de Roma, esperando retornar a Portugal em um cargo mais próximo do rei. Além do mais, o embaixador argumentava ter importantes informações da corte papal e de Portugal, e que o rei deveria prezar por ele, caso contrário, suas informações poderiam passar por indesejados: “alem de Vossa Alteza fazer mui grande merce em me dar licença em tempos tam perigosos, cumpre muito a seus serviços ouvir me, e saber muitas cousas que em carta nam se pode nem dizer". ${ }^{2}$

Tão importante quanto saber o que e como escrever, sobressaía na correspondência dos embaixadores a necessidade de ocultar informações e manter silêncio quanto a certos assuntos. A situação era também uma das instruções de D. João III nas negociações com os soberanos europeus. De acordo com a recomendação do monarca, haveria uma regra geral nas negociações, em que era necessário ter prudência adequada, para reconhecer o momento de fala e o de silêncio: "quero que o façaes, leixando a vos fazerdes o que la virdes que mais comprira a meu serviço de dizerdes ou calardes segundo vos milhor parecer". ${ }^{73}$ Mas na escrita das cartas entre o rei e os embaixadores, um importante momento de silêncio notado, serviu como uma forma de assegurar os negócios em Roma. Henrique de Meneses ao chegar na Cúria romana, notou que havia poucas respostas do rei, que preferia responder a D. Martinho com quem também dividia a embaixada. Logo, o embaixador escreveu a D. João III, pedindo para retornar a Portugal, e deixar que suas funções fossem exercidas apenas por D. Martinho:

Porque, eu, senhor, ha oyto meses que qua sou sem fazer nada, e em quatro acabara tudo se Vossa Alteza quysera mandar recado a seu tempo deuydo; e estar nesta casa da feyção que estou e como vym, e tanto tempo, nom parece ja bem, e mudar me pera outra, como la dizia a Vossa Alteza, como vym a esta, ja nom pode ser que pareça uoso seruyço nem honra de noos ambos, e por yso, senhor, Vossa Alteza me deuya de me mandar hyr consyderando primeiro muito bem se será isto asy mais vosso serviço. ${ }^{74}$

Entretanto, a resposta de D. João III veio apenas com um breve aviso que o pedido de Henrique de Meneses seria respondido em outra carta: "E as outras cousas que me

72 D. MIGUEL DA SILVA. “Carta a D. João III de o2 out. I522”. In: CDP. Vol. 2, p. Ioo.

73 D. JOÃO III. “Carta a António de Ataíde de 22 set. I537”. In: FORD, Jeremiah Denis Matthias. Op. Cit., p. 35I. Sobre a prudência nos assuntos de governo, ver em: PARDO MOLERO, Juan Francisco. "Gobernar según la virtud en la Monarquía Hispánica”. In: Idem. El gobierno de la virtud. Política y moral en la Monarquía Hispánica (siglos XVI-XVIII). Madrid: FCE, Red Columnaria, 2017, pp. 9-27; Sobre a prudência no oficio dos embaixadores, ver em: FRIGO, Daniela. "Prudence and Experience: Ambassadors and Political Culture in Early Modern Italy". Journal of Medieval and Early Modern Studies. № 38 (I), 2008, pp. 15-34.

HENRIQUE DE MENESES. “Carta a D. João III de 2I ago. I534”. In: CDP. Vol. 3, pp. 86-87. 


\section{REVISTA ANGELUS NOVUS}

nelas apontaes vos Responderei por outra carta, e nesta somente ao que toca a este episodio [a respeito do negócio da Inquisição]" .75 Essa não era, entretanto, a resposta desejada por Henrique de Meneses, que procurava com insistência novas respostas, utilizando de todos os tipos de argumentos: "E nom serya mao, antes de se acabar o officyo de sua coroação, termos auyso de Vossa Alteza do que faremos, e a ele [o papa] escreuer e vysitar".$^{76}$ Apenas em maio de 1536, quando teve pôr fim a promulgação da bula da Inquisição, que era o negócio que o rei esperava que fosse resolvido, que o embaixador foi autorizado a retornar a Portugal. ${ }^{77}$ Pela carta de Álvaro Mendes de Vasconcelos, enviado a Roma junto ao imperador Carlos V, é que se apontam os prováveis motivos do silêncio de D. João III: "Suprico Vossa Alteza que tenha por certo que nam he cousa pera fazer conta della, e dom Anrique nam pequou nem errou maliciosamente, antes escriuia zombando (...) e parti se ha feliz desta terra co a Bulla da Inquisiçam”.$^{78} \mathrm{O}$ rei preferiu manter silêncio do pedido do embaixador à espera da resolução do negócio em Roma, ao mesmo tempo que demonstrava descontentamento com as cartas de Henrique de Meneses. Em certo aspecto, escrever a tudo que era solicitado e em apenas uma missiva, foi considerado inoportuno e fora do devido momento. ${ }^{79}$

A manutenção do segredo e a possibilidade que a mensagem não circulasse de forma incontrolável era uma preocupação constante no envio de cartas e das rotas de comunicação. Contudo, essa não era uma apenas uma preocupação restrita aos embaixadores, a segurança da comunicação com os domínios ultramarinos, do mesmo modo, estava sempre presente. Para a defesa das naus que seguiam para a Índia, D. João III buscou organizar um sistema de rotas e paragens durante o trajeto, de forma a impedir que fossem interceptadas por corsários e diminuir os naufrágios. ${ }^{80}$ Organizadas para seguirem as correntes marítimas e as rotas dos ventos, D. João III pedia em segredo

75 D. JOÃO III. “Carta a Henrique de Meneses de 3 set. I534”. In: CDP. Vol. 3, p. 90.

76 HENRIQUE DE MENESES. “Carta a D. João III de I3 out. 1534”. In: CDP. Vol. 3, p. 120.

77 Na carta de 3 de maio de 1536, vinte dias antes da promulgação da bula Cum ad Nibil Magis que autorizava a Inquisição, Henrique de Meneses avisava do seu retorno a D. João III após a chegada de Pedro de Sousa de Távora, o novo embaixador na Cúria: "Senhor. Por este mesmo correo derradeiro recebi, de nom sei quem, duas cartas de Vossa Alteza, huma sobre cousas de tomar, que eu já nom poderei fazer e deixai as ey ao embaixador, como Vossa Alteza manda”. HENRIQUE DE MENESES. "Carta a D. João III de 3 mai. 1536". In: CDP. Vol. 3, p. 30I.

78 ALVARO MENDES DE VASCONCELOS. "Carta a D. João III de 2 mai. 1536 ”. In: CDP. Vol. 3 , p. 300.

79 Como adverte Eni Puccinelli Orlandi, o silêncio: "não é a ausência de palavras, a incompletude da linguagem, ou o sem-sentido, mas o indício de uma instância significativa". ORLANDI. Eni Puccinelli. As formas do silêncio: no movimento dos sentidos. 6a ed. Campinas/SP: Editora da Unicamp, 2007, p. 68. Ver também em: BURKE, Peter. A Arte da Conversação. São Paulo: Editora da Unesp, 1995.

I76 • ano XI, n. I6, $2020 \cdot \mathrm{ISSN} 2179-5487$ 
a Pedro Lopes de Sousa, capitão-mor da "armada da guarda", que fizesse paragens próximo as ilhas da Madeira e de Cabo Verde, onde havia maior incidência de corsários e para socorro das armadas que retomavam a Portugal: "E o que ey por bem que faça, da maneira que vollo por esta carta escrevo, lhe nõ dareis por escrito, somente lho direys por palavra em segredo, porque asy o ey por meu serviço". ${ }^{81}$

Posteriormente, também optou-se por passagem das naus na costa do Brasil após a ocupação das primeiras povoações, ${ }^{82}$ entretanto, além da mudança no itinerário das viagens, não era descartada a possibilidade do envio de informações pelo Mar Mediterrâneo, cruzando os caminhos que passavam por domínios otomanos. Durante o reinado de D. João III, espiões de origem judaica e armênia foram empregados pelo monarca, a fim de notificá-lo sobre a praça de Ormuz, mas muitos acabaram sendo aprisionados e retidos em Constantinopla. Em 1537, por exemplo, Álvaro Madeira, natural de Sousel no Alentejo, conseguiu escapar, chegando até a cidade de Roma. Segundo o embaixador Pedro de Sousa de Távora, Madeira informava que havia saído da Índia com trinta e quatro portugueses que após tentarem cruzar Israel, foram capturados pelo "gram turco solymam". Enquanto uns foram vendidos para comerciantes genoveses, e outros permaneceram em Constantinopla, convertendo-se ao islamismo, Madeira escapou para a Roma em uma nau veneziana que depois seguiu para Lisboa: "E porque elle vem muy destroçado, me pareceo necessario escreuer esta, a qual duplicarei por outras vias, e tras ella ira com ajuda de nosso Senhor o mesmo autor com toda a presteza possiuel”. ${ }^{83}$

8o As paragens, como um termo náutico, indica as posições próximas a costa utilizadas para aparelhar as velas e esperar a chegada de outros navios. Ver: BLUTEAU, Raphael. Op. Cit.,. Vol. 6, s. v. "Paragem", p. 253.

8I D. JOÃO III. “Carta a António de Ataíde de io mar. 1536”. In: FORD, Jeremiah Denis Matthias. Op. Cit., p. 259. Havia três armadas permanentes no reino que protegiam a costa portuguesa de invasões estrangeiras: A Armada da Costa ou da Guarda que mantinha embarcações até o cabo da Finisterra na região da Galícia, a Armada do Estreito, que atravessa a costa do Algarve, norte da África e o Mediterrâneo; e a Armada das Ilhas que compunha a defesa mais afastada do reino, entre o arquipélago dos Açores, ilha da Madeira e Cabo Verde. PIMENTA, Alfredo. D. João III. Porto: Livraria Tavares Martins, 1936, p. 45.

82 Vale lembrar que a passagem das naus com destino a Índia pelo Brasil, foi revista na regência do cardeal D. Henrique, durante a menoridade do rei D. Sebastião, que optou por passagem mais curtas e que as naus "invernassem" apenas no retorno a Portugal, devido as constantes percas de embarcações. Ver alvará régio de 6 Março de 1565 , em: SISTEMA, OU COLLECÇÃO DOS REGIMENTOS REAES. Vol. 6. Lisboa: Francisco Luiz Ameno, I791, p. I2.

83 PEDRO SOUZA DE TÁVORA. “Carta a D. João III de i9 jul. 1537”. In: CDP. Vol. 3, p. 397. Sobre os espiões enviados por D. João III, ver em: DISNEY, Antony. "The development during the reign of João III of communications between the Estado da India and Portugal via the Middle East". In: CARNEIRO, Roberto; MATOS, Arthur Teodoro de. Op. Cit., pp. 593-6oo. Sobre o aprisionamento de cativos ao longo do Mediterrâneo: HERSHENZON, Daniel. The Captive Sea. Slavery, Communication, and Commerce in early modern Spain and the Mediterranean. Filadélfia/ 


\section{REVISTA ANGELUS NOVUS}

Com efeito, assegurar o envio de informações de Portugal à Índia, passava ainda por impedir que os emissários tivessem conhecimento do que transportavam. Para isso, foi pedido que a correspondência fosse colocada em diferentes sacos para diferentes correspondentes, além de serem armazenadas em meio à carga do navio, escondida entre as mercadorias, com o intuito de passarem por despercebidas e burlar interceptações. Para informar sobre as finanças ao vedor da Índia, D. João III buscou impedir que mesmo os fidalgos do rei, como Antônio de Ataíde, soubessem o que continha nas cartas:

Conde Amiguo (...). Estas duas cartas que vos envio pera o doutor Pero Vaaz, veeador de minha fazenda na Imdia, sam sobre huua cousa de muyto meu serviço, que se ofereçeo depois de serem idos de ca os saquos das vias que agora vos nam sprevo, por seer secreto e se poder esta carta perder. Encomendovos muito que as emtregues ás pesoas que levam as vias, e as mãday coser nos saquos das ditas vias do dito veeador da fazenda, de maneira que se nam perquam, neem posam esqueçer ca neem lla, e que lhe sejam dadas em sua maão, porque, se se perdessem, perderya muyto. ${ }^{84}$

Aos embaixadores, uma das estratégias de assegurar o envio das mensagens secretas estava na inscrição de símbolos e caracteres que escondiam informações relevantes. Muitas vezes, esses símbolos podiam fazer referência à organização das etapas que a negociação teria, além de estarem colocados em diferentes posições no papel, aparentando terem sido feitos por descuido, como uma mancha de tinta ou um risco. Dessa forma, apenas os endereçados da correspondência poderiam decifrar sua mensagem. Foi o que D. João III instruiu a Antônio de Ataíde, quando foi por embaixador extraordinário na corte de Carlos V, no ano de I53I:

E asy porque nas ditas cartas vaão alguas cousas que aimda servem e se ham de fazer, asy como pelas ditas cartas veres, e levam as taaes na margem huua cruz, e vaão atadas as Reegras com huum Risquo do que ha de fazer, farees o que nelas se cõteem; a saber, aquelas que levam o dito synal. ${ }^{85}$

As cartas também podiam assumir uma escrita criptografada, chamada de cifra, compostas de sinais diferentes para cada letra, o que permitiria mudar a forma da

US: University of Pensilvania Press, 2018.

84 D. JOÃO III. "Carta a António de Ataíde de 2 mar. 1535”. In: FORD, Jeremiah Denis Matthias. Op. Cit., p. 219.

85 D. JOÃO III. “Carta a António de Ataíde de is ago. I53I”. In: FORD, Jeremiah Denis Matthias. Op. Cit., p. 58. Para as técnicas de esteganografia, forma de se esconder mensagens, usando sinais e marcas d’agua, Emrah Safa Gürkan dá o exemplo da tinta de vitriolo romano, ou sulfato, empregada pelos espiões de Carlos V e Felipe II que só era possível de ser legível após o contato com água e limão. Além do ulak (correio otomano) empregado pelos emissários em Veneza que utilizavam de nomes cristãos para a comunicação com os vizires em Constantinopla. GÜRKAN, Emrah Safa. Op. Cit., pp. 8I e $4 \mathrm{I} 3$.

I78 • ano XI, n. I6, $2020 \cdot \mathrm{ISSN} 2 \mathrm{I} 79-5487$ 
escrita, para que chegasse ao destino por meios diferentes, escondendo seu conteúdo ou mesmo os remetentes das missivas. A prática não era uma exclusividade do reinado de D. João III, haja vista que desde D. João I (I385-I433) e D. Duarte (I433-I438) já se encontram elementos de textos cifrados na correspondência com os embaixadores. ${ }^{86}$ Não obstante, em princípios do século XVI, as cifras eram empregadas constantemente como via de garantir a chegada das mensagens e os reis portugueses instruíam seus embaixadores a utilizarem como um dos principais recursos para assegurar as mais importantes informações. Em carta ao embaixador Pedro de Mascarenhas, D. João III o lembra: "Vós levaes cifras: por ellas me escreueres aquelas cousas que forem de tal calidade que por outra nenhuma via vos pareça que se me deve escreuer”. ${ }^{87}$

Sistemas de comunicação paralelos as rotas de comunicação, também se desenvolveram em outras cortes para reter importantes informações estratégicas. ${ }^{88}$ Por conseguinte, os secretários dos governantes, responsáveis pela codificação e decifração das cartas, tornaram-se imprescindíveis para o desenvolvimento dos sistemas comunicativos. ${ }^{8}{ }^{9}$ Antônio Carneiro e seu filho Pero de Alcáçova Carneiro tiveram especial destaque na escrita aos embaixadores em Portugal, tanto que as cartas cifradas, muitas vezes, eram a eles endereçadas para que se incumbissem de decifra-las. Como informa D. Martinho: "Na carta de sua alteza uão os negócios, [nesta] screuo esta cyfra desta maneira e asi queria que as cousas de importância, se socedessem, uierem, scritos as regras tão largas pera nom se perder e por cyma decyfrar"..$^{\circ \circ}$ No entanto, vale destacar, que Pero de Alcáçova Carneiro narra em sua Vida do Conde da Idanha, não ter sido responsável pela escrita apenas aos embaixadores, mas também ter participado de diversos momentos das missivas de D. João III:

E quando El-Rei escrevia para a Rainha, em qualquer matéria sobre que lhe escrevia, estava eu sempre presente, e lhe fechava as cartas, depois de as Ele escrever; e as que escrevia por sua mão ao Papa, ao Imperador, aos Reis e Príncipes, e as Princesas, suas filhas, eram todas notadas por mim, e de casa lhe trazia as minutas delas, e algumas vezes as emendava, e outras as fazia de

86 MARINHO, Duarte Maria Monteiro de Babo. "Diplomacia e espionagem na baixa Idade Média portuguesa”. In: VIGIL MONTES, Néstor (org.). Comunicación politica y diplomacia en la Baja Edad Media. Évora/PT: Publicações do CIDEHUS, 2019, p. 193.

87 D. JOÃO III. “Carta a Pedro de Mascarenhas de 29 mai. I538”. In: CDP. Vol. 4, p. 420.

88 TALLON, Alain. Op. Cit., pp. I6I-165.

89 Vale mencionar Antônio Perez, secretário de Felipe II, Ambrógio Ricalcato, secretário papal de Clemente VII e Paulo III, além de Francisco de los Covos e Alonso de Idiáquez, secretários de Carlos V. Alonso de Idiáquez, inclusive, foi dedicado por Juan Luís Vives com um manual para escrita das cartas De Conscribendis Epistolis, a fim de auxiliá-lo em matérias do governo. GÜRKAN, Emrah Safa. Op. Cit., p. 84.

90 D. MARTINHO DE PORTUGAL. "Carta a Pero de Alcáçova Carneiro de 30 dez. I526". In: CDP. Vol. 2, p. 283. 


\section{REVISTA ANGELUS NOVUS}

novo: e Ele notava, e eu escrevia, e tudo por me querer antes mostrar mais favor, e dar nisso doutrina e ensino, que por necessidade que para isso houvesse". ${ }^{9}$

Os embaixadores também não eram os únicos a escreverem em cifras. Duarte de $\mathrm{Paz}$, procurador dos cristãos-novos em Roma (que buscava impedir que a Inquisição fosse instaurada no reino) buscou "presentear" D. João III com um modelo de como viriam suas cartas: "enuio a Vossa Alteza este abc das cifras, que Vossa Alteza mande guardar, porque as cousas desta calidade por elas lhe escreverey, por me nom suceder algum perigo aa pessoa tomando alguma minha letra”. ${ }^{22} \mathrm{O}$ procurador enviava para $\mathrm{o}$ rei um modelo para se escrever cartas cifradas, o "abc das cifras", ademais ele assinava a carta também de forma cifrada, como mostra a imagem a seguir: 
Figura I: Carta de Duarte de Paz a D. João III de 4 nov. I532

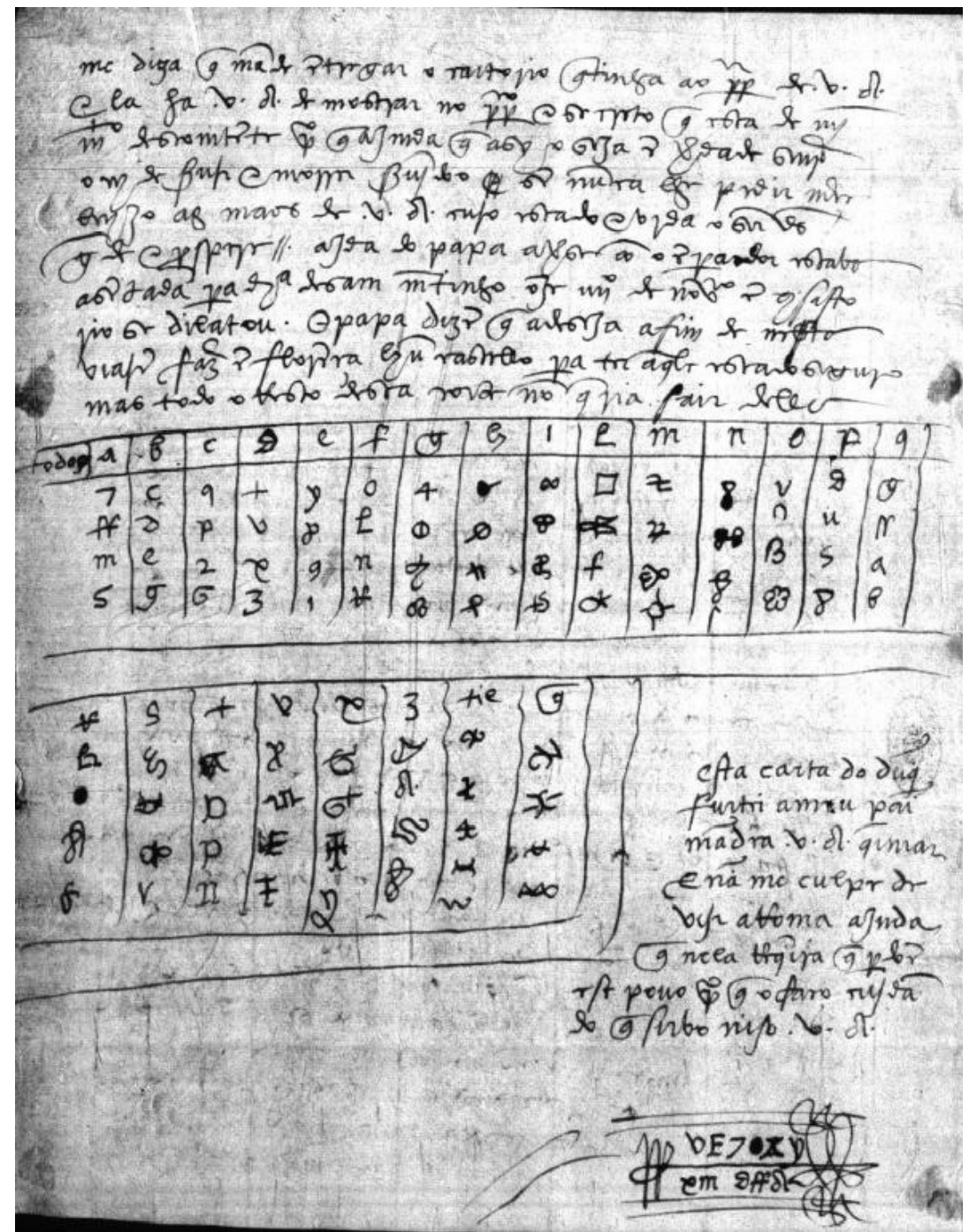

Fonte: ANTT, CC, Parte I, maço 49, doc. 2o. Disponível em: «https://digitarq.arquivos.pt/details?id=37735I8». Acesso em: Io abr. 2020. 


\section{REVISTA ANGELUS NOVUS}

As cifras de Duarte de Paz mostram uma variedade de caracteres, quatro ou cinco para cada letra, o que ilustra a grande necessidade do procurador em assegurar a mensagem, dificultando a compreensão do texto, em caso de interceptação. ${ }^{93}$ Para além disso, a diversidade de caracteres, letras, números e diversos outros símbolos indicam um vasto conhecimento que o promotor tinha na linguagem cifrada, reflexo do período em que teria sido espião de D. João III, antes de ir a Roma, representar os interesses dos cristãos novos. ${ }^{94}$ Aos embaixadores, pelo menos para D. Miguel da Silva, o número de caracteres das cifras como letras e números eram mais usuais, indicando uma "chave única” para uma ou mais letras do alfabeto:

Quadro I: Cifras do embaixador D. Miguel da Silva.

\begin{tabular}{|c|c|c|c|c|c|c|c|c|c|c|c|c|c|c|c|c|c|c|c|c|}
\hline a & b & $\mathrm{c}$ & $\mathrm{d}$ & $\mathrm{e}$ & f & $\mathrm{g}$ & $\mathrm{h}$ & $\mathrm{i} / \mathrm{j} / \mathrm{y}$ & 1 & $\mathrm{~m}$ & $\mathrm{n}$ & o & $\mathrm{p}$ & q & $r$ & $\mathrm{~s}$ & $\mathrm{t}$ & $\mathrm{u} / \mathrm{v}$ & $\mathrm{x}$ & $\mathrm{z}$ \\
\hline 8 & 5 & 7 & 3 & 2 & 9 & 6 & 5 & 4 & با & $x$ & $\gamma$ & $A^{c}$ & o. & $S$ & $m$ & 6 & 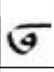 & $\xi$ & $\gamma^{\circ}$ & 8 \\
\hline 8 & $\hbar$ & 7 & 3 & 2 & 9 & 6 & h & 4 & $\Perp$ & $x$ & $y$ & ff & $\mathrm{d}$ & 5 & $\mathrm{~m}$ & $\mathrm{v}$ & $q$ & $\underline{\mathrm{h}}$ & $\underline{x}$ & $b$ \\
\hline
\end{tabular}

Fonte: CRUZ, Maria Augusta Lima; LÁZARO, Antônio Manuel. "A linguagem criptografada na correspondência diplomática portuguesa de D. Miguel da Silva e de Pêro Correia: origens e significado". In: CARNEIRO, Roberto; MATOS, Arthur Teodoro de. Op. Cit., p. 606.

Durante a trégua entre Francisco I e Carlos V na primeira metade da década de I520, discutia-se na Cúria romana a possibilidade de se iniciar um novo conflito entre os monarcas e quais seriam os locais de batalha. D. Miguel da Silva ao indicar a D. João III, uma conversa secreta que teve com o papa Clemente VII, a respeito de uma informação do núncio na França, preferiu cifrar certas passagens da missiva:

Senhor. Depois de escrito o que nesoutras minhas cartas me mandou chamar o papa e me disse que escrevesse a Vossa Alteza como naquele ponto Reçebera cartas 32 v2 $\underline{\mathrm{h}}$ y $\underline{\mathrm{hm}} 74 \mathrm{ff} 32 \mathrm{9m} 8 \mathrm{y} 78$

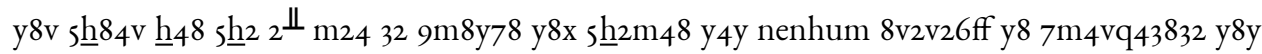

93 As cifras foram também publicadas em: PIMENTA, Alfredo. Op. Cit., p. in8. Vale ressaltar que embora o procurador tenha assinado como Duarte da Paz, o uso do "de Paz" era mais comum entre os membros da família. Sobre Duarte de Paz, ver em: VALENTIN, Carlos Manuel. "Duarte de Paz: um líder da comunidade sefardita portuguesa em meados do século XVI”. In: REIS, Fátima (org.). Rumos e Escrita da História. Lisboa: Edições Colibri, 2007, pp. 175-190; NOVOA, James Nelson. "The Departure of Duarte de Paz from Rome in the Light of Documents from the Secret Vatican Archive”. Cadernos de Estudos Sefarditas. № 7, 2007, pp. 273-300.

94 Além de ter servido a Coroa como requeredor dos portos secos da Beira e feitor da Alfândega dos panos, marçaria e herdades da cidade do Porto, Duarte de Paz teria sido espião de D. João III, antes de ir a Roma. PIMENTA, Alfredo. Op. Cit., p. 179; VALENTIN, Carlos Manuel. Op. Cit., p. I82.

I82 • ano XI, n. I6, $2020 \cdot \mathrm{ISSN} 2 \mathrm{I79}-5487$ 
BARROSO • "Comunicação política e diplomática no reinado de D. João III”

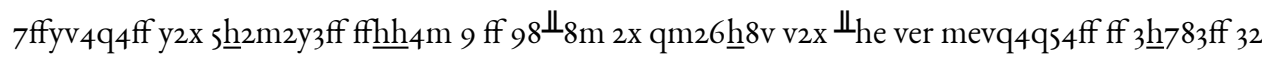
$\mathrm{x}_{4} \Perp_{8 \mathrm{ffx} .95}$

A mensagem era que o rei francês optaria por romper a trégua com o imperador e atacaria o ducado de Milão, informação que seria útil para Carlos V, mas o embaixador sabia que poderia comprometer os interesses de D. João III com o Francisco I e até mesmo com o papa. Visto que entre D. João III e o Carlos V estavam em disputa pelas ilhas Molucas, com a recente viagem de Fernando de Magalhães e o papa negociava com o rei francês o casamento de sua sobrinha, Catarina de Médici, com o delfim da França, Henrique (futuro Henrique II), em uma liga contra o imperador:

Senhor. Depois de escrito o que nesoutras minhas cartas me mandou chamar o papa e me disse que escrevesse a Vossa Alteza como naquele ponto Reçebera cartas de seu núncio de frança nas quais via que el rei de frança nam queria nin nenhum asesuguo na cristindade nam consistindo nin querendo ouvir fo falar em pas nem em treguas sem lhe ser restituído o ducado de milaom. ${ }^{96}$

Embora mesmo uma correspondência cifrada não asseguraria que a mensagem não fosse interceptada, pois, o uso das cifras não era exclusividade dos embaixadores portugueses, já sendo de conhecimento de diversas cortes europeias. Em I534, Etienne Dollet, impressor do rei da França, aconselha o bispo de Limogenes e embaixador em Veneza, Jean de Langeac, que em matérias que demandam sigilo, deve-se comunicar ao rei apenas em "caractères inconnus" ${ }^{97}$ Além do mais, códigos também eram altamente empregados, como falar em "malagueta" para se referir a rainha Leonor, "maças" para o papa Médici, ou ainda o "negócio principal” para a Inquisição, o que demonstra os vastos elementos presentes na comunicação. ${ }^{98}$ No entanto, o desconhecimento do significado das cifras poderia dificultar a compreensão da mensagem, visto que, em certa medida, apenas os embaixadores e espiões eram "treinados" para conhecê-la. O infante D. Luís, duque de Beja, quando foi liderar a armada portuguesa na batalha de Túnis em I535, escrevia sobre a incapacidade de ler a carta cifrada do rei, devido a não ter um "abc" que ajudasse, nem a ele, ou ao imperador:

D. MIGUEL DA SILVA. “Carta a D. João III de io jun. I523”. In: $A N T T$, CC. Parte I, maço 29, doc. 79 .

96 Ibidem.

97 DOLLET, Étienne. "De Officio Legati". In: DUNLAP, James. "Étienne Dollet of Orleans, France”. The American Journal of International Law. Vol. 27. № I, 1933, p. 86. Ver também em: GALENDE DIAZ, Juan Carlos. "La escritura cifrada durante el reinado de los Reyes Católico y Carlos V". Cuadernos de estudios medievales y ciencias y técnicas historiográficas. XVIII-XIX, 1994, pp. 159-178. 


\section{REVISTA ANGELUS NOVUS}

E se algua d'essas cousas me vynha na cyfra que sua alteza me mandou, sabey que a não ly, porque o abc do emperador he perdydo, e elle ja o tem escryto de Cerdenha [Sardenha], por onde eu creo que não pode tardar outro correo que traga outro abc ou decraraçam da cifra que qua eu tenho. 99

Há ainda de se ressaltar que a incompreensão da linguagem cifrada poderia se assimilar a uma linguagem demoníaca. No processo do médico Eugênio de Torralba de I528, acusado de nigromancia e blasfêmia pelo tribunal de Cuenca, Diego de Zuniga testemunhou que quando estava a serviço do papa Adriano VI em Roma, Torralba lhe pediu que levasse uma carta ao cardeal Vulterra a respeito de um jogo de cartas que tiveram. A carta tinha caracteres que Zuniga desconhecia e que segundo ele, tinha sido escrita com sangue de morcego, como parte de um ritual que profanava contra símbolos da fé católica:

Se acuerda el dicho testigo [Diego de Zuniga], que en la cedula havia ciertos caracteres, y en medio della una cosa redonda del tamaño de una Ostia, que le parece a este testigo que se enderezaba a cosa del Sanctissimo Sacramento del Altar; y que el dicho Doctor [Eugênio de Torralva] dixo a este testigo que aquello era una figura como Ostia, y que no se acuerda bien como lo dixo por haver ocho años o nueve pasados. ${ }^{100}$

As diferentes formas de manutenção de segredos empregadas pelos embaixadores demonstram o considerável protagonismo que tiveram na condução das ações políticas ao longo do reinado de D. João III. A experiência nas cortes europeias, principalmente em Roma, centro da cristandade, ocorreu em um cenário de intensas disputas por informações e por espaços de representação na corte. Foi a partir dessa disputa que os soberanos europeus investiram largamente em cerimônias para exporem seu poder frente ao papa, aos cardeais e a outros senhores e enviarem os mais ilustres cortesãos do reino, letrados, humanistas e os mais proeminentes juristas e teólogos, não apenas em missões protocolares e esporádicas, mas também para residirem nas cortes e informarem o soberano sobre tudo. Com D. João III não foi diferente. A fim de coletarem as mais preciosas notícias e informarem a Coroa, os embaixadores portugueses desenvolveram diversas técnicas de escrita e do envio de informações que possibilitaram o conhecimento sobre as ações e alianças dos vizinhos. Além do mais, foram sumariamente importantes, para garantirem a autonomia do reino, a concessão de

99 D. LUÍS. "Carta a Antônio de Ataíde de 25 jul. I535". In: FORD, Jeremiah Denis Matthias; MOFFATT, Lucius Gaston. Op. Cit., p. 19.

ıоo "Processo de Eugenio de Torralba - medico vezino de Cuenca". BNP. Cód. 1969, folha 25v. Vale dizer que Eugenio de Torralba tinha conhecimento de hebraico, o que não necessariamente signifique que tenha escrito de forma cifrada. Sobre a condenação de Torralba: BAROJA, Juan Carlo. Vidas mágicas e Inquisición. Madrid: Ediciones ISTMO, 1992, pp. 231-294.

I84 $\bullet$ ano XI, n. I6, $2020 \cdot \mathrm{ISSN} 2179-5487$ 
bulas para a criação de tribunais inquisitoriais, a defesa do comércio e dos domínios ultramarinos.

\section{Considerações finais}

$\mathrm{O}$ aumento do quadro diplomático durante o reinado de D. João III veio conjuntamente à modernização dos sistemas de comunicação, criação do correio régio e com o aprofundamento das relações com as cortes, como a do imperador e do papa. Diversas possibilidades de escrita e envio de informações eram, nas palavras de D. João III, sinônimo de "tempos de qualidade", ou seja, era necessário que Portugal, como um reino independente, estivesse sempre a par das informações que circulassem. No entanto, para assegurar a chegada das mensagens foi preciso desenvolver técnicas de escrita e codificação dos textos, além de alterar as rotas e esconder a correspondência. Além do mais, a criação das embaixadas permanentes foi também um esforço da Coroa em ter autonomia diante das maiores autoridades no momento, o papa e o imperador. Dessa forma, expandiu-se os canais de comunicação constantes, independentes e regimentados por diferentes vias, como pelo comércio, rotas de peregrinação, aperfeiçoamento dos transportes marítimos e pelo uso da espionagem.

Nesse sentido, a comunicação do rei com os embaixadores precisou se adequar cada vez mais às exigências do transporte, às dificuldades na navegação, aos assaltos aos mensageiros quando passavam por terra ou por mar, e às conflituosas relações militares. Porém, foi em um diálogo permanente, embora muitas vezes remoto, entre os membros do Conselho do rei, as embaixadas e os servidores nos domínios ultramarinos, que foi possível articular o governo, instruir as ações no reino e tomar conhecimento sobre os territórios de domínio da Coroa e seus vizinhos europeus. Assim sendo, investigar a correspondência dos embaixadores de D. João III demonstra como as formas de comunicação foram desenvolvendo a partir da grande demanda de informações. Fruto de um processo de conexões entre as coroas e os soberanos europeus da primeira Idade Moderna, pautada pela crescente disponibilidade de novas vias de comunicação e aperfeiçoamento dos transportes. 